○牧野浩二、小宗静男、東野哲也、中野隆之、井手稔、森满保 (宮崎医科大学耳鼻咽喉科)

Canrenoate potasium, カンレノ酸カリウムは、抗アルドステロン郕の第 7 位のチオア セチル基が外れ、1 7 位のラクトン䍗が、開裂し水溶性となったものて、をの抗アルドス テロン作用はスピロノラクトンより強力で静注により、腎の遠位尿細管におけるNa再吸収 の抑制による利尿作用を示す。類似の作用機序により利尿作用を示すものにフロセマイド

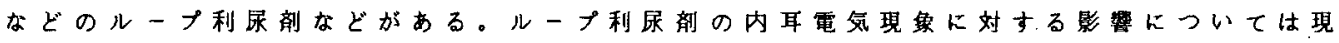
在まで数多く報告されているが、カンレノ酸カリウムについての報告は禾だない。組織学 的变化については、中井らの報告をみるのみてあって：をれによれば $200 \mathrm{mg} / \mathrm{kg}$ 力ンレノ 酸カリウムの静注により血管条辺縁細胞が選択的に障害されるが、中間細胞、基底細胞に 変化はなく、又、有毛細胞にも变化は嫼められないという。以上のような薬理機序また内 耳の組織学的变化加ら、本薬剂は、EP特にその正成分のみに影整を与えることが予想さ

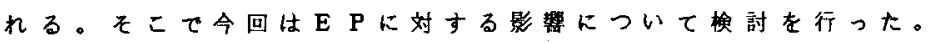

(実就材料と方法)

実験動物にはプライェル反射良好なモルモットを使用し、ネンブタール15mg/kg 腹腔内 投与によって麻酔し、気管切開後サクシン $15 \mathrm{mg} / \mathrm{kg}$ 投与による非動化、呼吸管理を行った 。E Pは、Ventral approachにて中耳骨胞を開放し、基底回転の螼牛管壁にあけた小孔よ

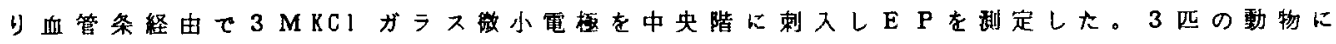

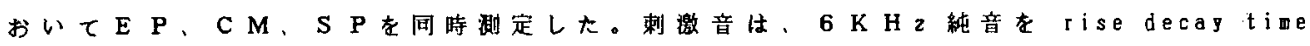
$2.5 \mathrm{msec}$, duration $50 \mathrm{msec}$ toneburstとして与えた。カンレノ酸かリウムは静註と外引 ンパ灌流の2つの方法により投与した。外リンパ灌流は基底回転鼓室階より同回転前庭階 人 $5 \times 10^{-3} \mathrm{M}$ 濃度カンレ, 酸カリウム落流速度約 $10 \mu 1 / \mathrm{min}$ 行った。

(結果)

1、静註群

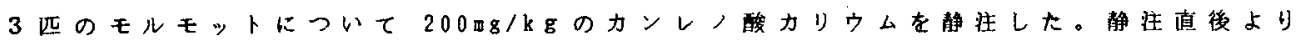
E P は数mV低下するがすぐに心停止がおこり全例死亡した。

2、外リンパ灌流群

(1) E P の变化

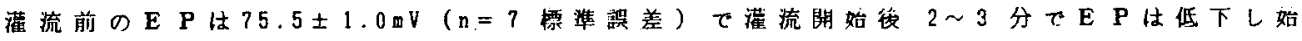
め、約 20 分後にほぼ一定の值 $19.3 \pm 6.7$ 四 $(n=?)$ となり 60 分までの経過でもあまり变化なか った。（表1）そこでほほP P.が一定とかった時点の30〜45分後にano8iaを目荷すると、

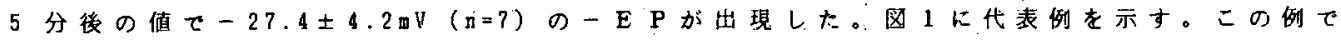

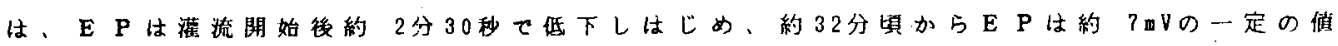

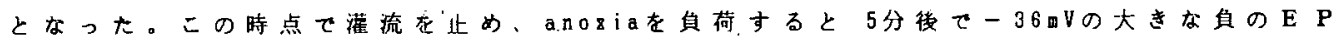
が出現した。呼吸再開後 EP は急逨に回復し始め、そのまま回復を続け灌流開始後59分後 には5 $0 \mathrm{mV}$ に回復した。そこで再度灌流を行うと再び同じバターンてEPは低下し、2回

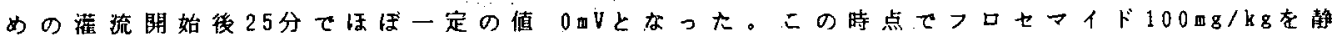
註するとEPは急速に低下し、同様に大きな負のE P が得られた。同梾のE $\mathrm{P} の$ 変化は動 物でも証められた。

(2) $\mathrm{C} M, \mathrm{~S}, \mathrm{P}$ P の変化

3 例について C M , S P , E P の同時㓪定を行なった。 C M の変化は E Pとほほ同様で Audiology Japan Vol. 26, No.4, $1983 \quad-311-$ 
あった。SPはEPが低下して安定する頃からーS P が增大する烦向があった。团 2 は代 表例を示してある。この例で E P が安定した時点でAno8iaに奶する5 分後のーEP值仕

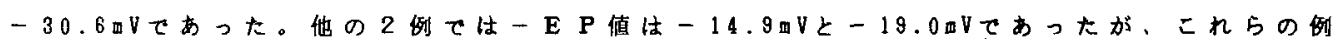
では比較的大きなーSPが得られた。

(3) 組学的観察

走查電㩆にて有毛細胞を観察した。2例の大きなーEPが得られたモルモットて有毛紐 胞を観祭したが、2例ともに内外有毛細胞は正常てあった。血管条の変化たついては检討 中である。

\section{( 結論)}

1) E P 注灌流開始後 $20 \sim 30$ 分で10数四前後の一定值となり60分後までの值を維持し たが、フロセマイドやェタクリン酸などの利尿倣の様な大きな負電位は発生しなかった。

2) E Pが一定になった時点て Anoxia にすると大きな目電位が得られたが、それらの 動物では走查電影にて有毛細胞には何の变化もみられなかった。

3) E P が一定になった時点て灌流を止めると、此較的すみやかに E P が回復する例が ほとんどの動物にみられた。これはカンレノ酸カリウムのEP発生細胞のレセプターに対 する結合が弱いことを示晙すると考元られる。
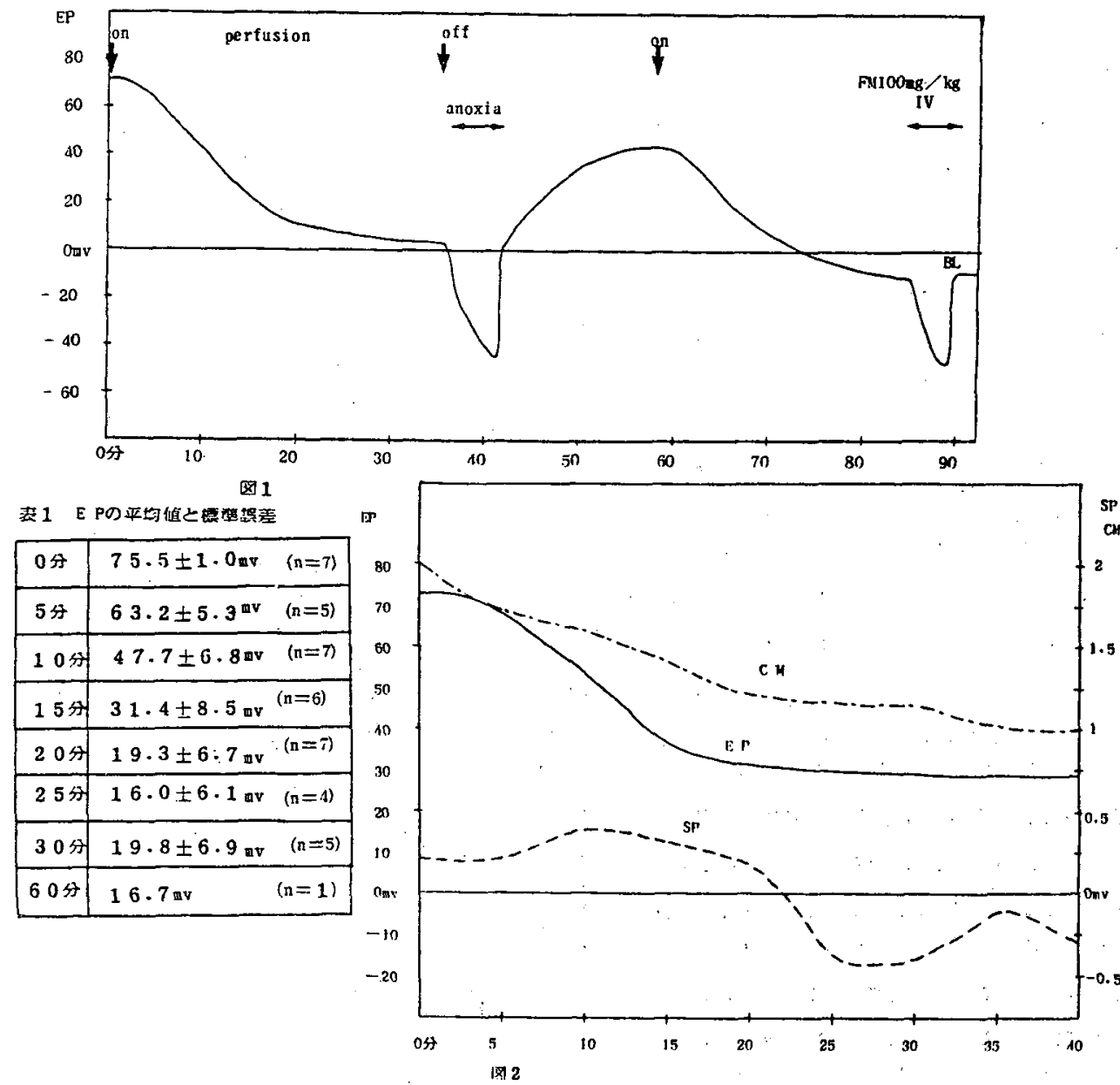